\title{
Innovation From the Perspective of Malaysian Women Entrepreneurs in Food-based Enterprise
}

\author{
Suraini Mohd Rhouse
}

\begin{abstract}
While innovation is important for firms' competitive advantage and economic development, knowledge about both innovation practices and models is based on large organizations, and the applicability of the findings of such research to women entrepreneurs who dominate the small businesses is limited. The aim of this study was to understand how innovation capability develops in women entrepreneurs in food-based enterprises.This study emphasized an interpretive approach in order to help deepen our understanding of the innovation capability among women entrepreneurs. A qualitative approach, grounded from a social constructionist theorizing was used. This study utilized the data from ten women entrepreneurs from the Northern States of Malaysia. Semi-structured interview was used to collect the data. The data were transcribed and categorized in order to find differences and similarities, and then analyzed using the thematic analysis. Based on ten women-owned businesses in this study the findings indicate that innovation was constructed in terms of the ability to capitalize on sophisticated machineries for innovation purposes. In addition, innovation was articulated in the form of new or improved products. Most women entrepreneurs develop their innovation capability from customer engagement, employee participation, networking, family members as well as from their owned experiences and expertise. From a policy perspective, innovation program specifically aimed at women entrepreneurs should be delivered effectively by the relevant agencies.
\end{abstract}

Keyword: Innovation Capability, Women Entrepreneurs, Food-Based Enterprise

\section{INTRODUCTION}

In Malaysia, women who manage their own business are widely active in consumer oriented and service business activities, for examples, activities related to health, social, or education. These activities take mostly place at the local level and therefore need generally relatively less resources. Women entrepreneurs are therefore under-represented in the transformational industry and in business-to-business activities. The Malaysian Statistic Department (2016) reports that women's participation in business is relatively low compared to that of men. The census showed that only 187,264 companies of the 920,624 active establishments nationwide were owned by women. In general, women entrepreneurs in Malaysia still dominate service sector areas such as education, retail trade, childcare, beauty and healthcare (NAWEM, 2016). Although women participation in economic activity has become a growing importance to

Revised Manuscript Received on June 22, 2019.

Suraini Mohd Rhouse, Faculty of Management and Economics, Universiti Pendidikan Sultan Idris(UPSI) the development of Malaysia there is a need to upgrade the level of woman-managed businesses from micro enterprises into small and medium scale businesses, focusing on strategic sectors such as education, health care, financial services, and information and communication technology. To fully understand women's innovation practices in Malaysia, it is critical to examine experiences of women entrepreneurs. Understanding of their innovation practices is likely to surface interesting insights into women-managed enterprises in Malaysia.

Scholarly research on innovation has focused on a diverse theme (Baregheh et al., 2009). The literature shows that the predominant work on innovation seeks to investigate the link between management and innovation (Drucker, 2014; Obeidat et al. 2016; Wolff \&Pett, 2006); business performance and innovation (Lofsten, 2014; Prajogo et al., 2013); and innovation processes in large firms (Barczak et al., 2009; Kodama, 2017). Innovation orientation also has been studied in women-owned family business (Gundry et al., 2014). While innovation is important for firms' competitive advantage and economic development, knowledge about both innovation practices and models is based on large organizations, and the applicability of the findings of such research to women entrepreneurs who dominated the small businesses management is limited. The majority of women-owned businesses are micro in size (88 per cent) followed by small ( 11.3 per cent) and medium size (0.8 percent) (Ilhaamie, 2014; Teoh\& Chong, 2014).

Although the phenomenon of women-managed entrepreneurship has proliferated due to significant increase in firms founded by women, research on women's managerial does not explicitly address the innovation capability per se. It is worth noting that research on womenmanaged enterprises tends to essential the category of women that is, assumes that all women, regardless of ethnicity, socioeconomic status, cultural background, religion, and other categories of difference, share exactly the same experiences and views (Nählinder et al, 2015;Peeters, L. W., \&Ateljevic, 2017).

Consequently, women entrepreneursin low profit or income enterprises who are involved in informal economy and microenterprises, are usually excluded from mainstream women entrepreneurs and innovation research. In addition, gender research continues to be dominated by Eurocentric paradigms, characterized by capitalist and secular ideologies (Syed, 2010). Indeed it can be said that the pervasive values

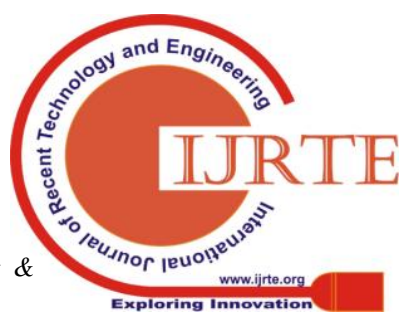


of Western models of entrepreneurialism which is characterized by innovation and risk taking, for example, have normalized the perception that all women entrepreneurs participate in the market-driven society. However, women entrepreneurs lived experiences are subject to multiple influences, and their different societal contexts such as economic condition will differently shaping their innovation practices and processes. How, then, might we robustly conceive of the experiences of women entrepreneurs practices on innovation?

It should be noted that in understanding women-manages innovation, it is a field of study that can be contributed to from a research on management, small business in relation to innovation, and small business growth amongst others. While the number of women operating their own business is increasing globally (Ambepitiya, 2016, Brush \& Cooper, 2012; Marlow et al., 2009) research shows that women entrepreneurs around the world are largely concentrated in small to medium scale enterprises and informal economy, which primarily includes retails and services (Ramadani et al., 2015; Terjesen et al., 2016). Malaysia is no exception. Women-managed small businesses are also characterized by low start-up capital, low barriers to entry, and offer lower returns (Al Mamun,Rajennd, Muniady, Permarupa, Zainol\&Malarvizhi, 2016; Teoh\& Chong, 2007; World Development Report, 2012).

Additionally, numerous studies have found that women are greatly affected by the needs to fulfill and to maintain traditional family roles and responsibilities (Rehman\&Roomi, 2012; Agarwal\&Lenka, 2015; Ilhaamie, 2014) which can influence the innovative capability of their businesses in the long run. In many small enterprises basic operational functions are implemented by the owner or manager of the firm, and not by the innovative entrepreneur, and this often leads to lack of knowledge needed to implement innovation within the firms. Moreover, economic changes, globalization, changing consumer demands, advanced technological capabilities, and decreasing product lifecycle all influence women entrepreneurs to implement the innovation practices within the firm (Kamariah et al., 2012).

Several studies also showed that small firms have difficulty in acquiring external capital for innovation purposes and thus they have difficulties in responding proactively to their markets (Tambunan, 2011). When compared to small firms, large firms have advantage of slack resources to implement innovation activities and are able to absorb losses as well if innovations fail (Fernandez $\&$ Wise, 2010). Here arises the importance of examining how do women entrepreneurs construct or develop their innovation capability given the small sizes of their companies.

Because women entrepreneurs dominated the small enterprises, they are associated with the liability of smallness, dependent on local resources and markets, and are less likely to benefit from technology and capital when compared with large firms' extensive in-house resources (for example, research and development, financial and manufacturing resources, networks, etc). These resources act as barriers to innovation for women entrepreneurs. In fact most women entrepreneurs are seen to engage in basic

goods and trade activities, and not high technology, skills or value added areas. The promotion of innovative activities in women's dominant business are seen to be lacking. Women's businesses in Malaysia are largely concentrated in service sectors and microenterprises (NAWEM, 2016) which generates less revenue which in turn affects their innovation capability and thus can make survival difficult for them.

Although women entrepreneurs have equal potential of bringing in innovativeness yet due to their limited resources and different business approach they are most of the times unable to manage their innovative capability in the long run. Moreover, women entrepreneurs have huge family, work and business responsibilities (Aziz et al., 2012). Despite the fact that the participation of women in businesses has increased substantially, there is little evidence of entrepreneurial innovation among women entrepreneurs. In addition, most SMEs especially in medium and large industries are owned by men entrepreneurs who have the tendency to participate in innovation activity due to the greater resources. Also despite the presumed existing opportunities and government programs for innovation support, there is lack of evidence on the sources of innovation capability from women entrepreneurs. Moreover there exist a bias for looking only at high-tech or industrialized sectors which has undermined the innovation conducted in other types of firms such as owned by women entrepreneurs (Hewitt-Dundas, 2006; Hirsch-Kreinsen, 2015; Thornhill, 2006). Given this gap, the present study aims to explore women entrepreneurs' innovation capability by understanding how they innovate their products to be competitive in the marketplace.

On top of that it is also important to identify factors influencing women entrepreneurs' innovation. More specifically, an evaluation of the relevant agencies who promote innovation is necessary in order to improve its effectiveness. Much less attention has, however, been paid to the women entrepreneurs' barriers in innovation. Given that women entrepreneurs are likely to take greater risks in building and sustaining their businesses it might be expected that women entrepreneurs, compared to entrepreneurs of established firms, view their innovation capabilities differently.

With respect to the above issues, the overarching objective of this study is to explore the innovation capability of women entrepreneurs in food-based enterprises in the Northern State of Malaysia.To achieve the above mentioned objectives, the research questions for this study are as follows:

RQ1. What does innovation mean to women entrepreneurs?

RQ2. How do women entrepreneurs construct or develop their innovative capability? 
The research study uses a social constructionist lens to increase our understanding of ways in which women entrepreneurs construct their innovation capability within their entrepreneurial life. This study also aims to increase our understanding of what does innovation mean to women entrepreneurs. Thus, the focus on understanding the subjective and interpretive experiences of women entrepreneurs can be enriched.

\section{LITERATURE REVIEW}

An earlier attempt to establish theoretical concepts of innovation came from Schumpeter (1934) which has triggered economists and researchers to stress the vital role of innovation to business growth. Innovation is conceptualized as introduction of new products and services, the introduction of new processes, the opening of new markets, or the introduction of new organizational forms (Crossan\&Apaydin, 2010). Innovation is commonly described as the generation of ideas, or introduction of something new, and modification of existing processes as well (Babalola, 2006; Chell, 2001).

In order to innovate, entrepreneurs must have innovative capability development which can influence the entrepreneurial success of enterprises (Hansen et al., 2011; Yuanjian et al., 2011). Terms such as innovation capacity, innovation capability, and innovative capability have been used interchangeably in the mainstream literature (Hogan et al., 2011). Hogan et al.'s (2011) provided a holistic view on innovation capability that is:

A firm's ability, relative to its competitors, to apply the collective knowledge, skills, and resources to innovation activities relating to new products, processes, services, or management, marketing or work organization systems, in order to create added value for the firm or its stakeholders (p.3).

The capabilities of the firms to implement innovation allow the firms to achieve sustainable competitive advantage. Innovative capability emphasizes on the capacity of entrepreneurs to develop new products by foreseeing the vision of market needs and trends, modifying and updating the process of product development, to satisfy customers' needs and counteracting uncertainties caused by competitors (Kamariah et al., 2012) and the ability to commercialize it (Prelazzi, 2009). It requires the skills, knowledge, and resources to effectively improve existing technologies and the ability to quickly introduce new products in order to meet changing customers' requirement (Tepic et al., 2012).

Scholarly research asserts that innovative capability has been acknowledged as an important factor in determining the successful growth of the firms (Subrahmanya et al., 2010; Lee \& Hsieh, 2010). Women although have equal potential of bringing in innovativeness yet due to their limited resources and distinct business approach they are most of the times unable to manage their innovative capability in the long run (Tambunan, 2011). Here arises the need to examine what influences the development of innovative capability of women entrepreneurs in Malaysia and how women perceive the process of innovating their products or services in order to compete in the marketplace. Because research on women entrepreneurs' innovation appears to be limited especially in the context of food processing, it is important to understand existing research on women entrepreneurs' innovation activities and capabilities. Existing study on women entrepreneurs in technical based businesses showed that human, social, and psychological capital can be seen to influence innovative capabilities (Dakhli\&Clercq, 2004; Wang et al., 2010; Yu \&Yanfei, 2009).

Along with the general education and skills needed for entrepreneurship development, technological skills also is crucial for entrepreneurs to innovate (Goswami\&Dutta, S, 2018; Kamariah et al., 2012). Other studies found that social networks, role models, entrepreneurial attitudes and family context are important determinants of women-managed entreprises in innovative sectors. A positive attitude towards innovation combined with a high need for achievement also has been shown to influence the success of women-owned firms (Lai et al., 2010).

The literature indicates a considerable body of research in the field of innovation and innovation capability. Numerous studies have been conducted to examine innovation in the entrepreneurial context (Heimonen, 2012; MohdRosli\&Sidek, 2010; Roig-Tierno, Kraus \& Cruz, 2018). The field of innovation is mainly inspired by the work of Schumpeter (1934) who developed innovation concept as the need for entrepreneurs to innovate new product / services, processes, new market, new industries and new supplies. In this sense, innovation goes beyond technology. Other studies have sought to improve on the Schumpeterian approach from a wider perspective, considering other dimension such as business culture, the role of the firms, collaborative engagements among firms, sources of innovation and learning process of the firms (Caceres et al., 2011).

It is generally agreed that innovation is a key driver for competitiveness and competitive advantage (Shoham\&Fiegenbaum, 2002). The past few decades has seen an evolution of innovation model from a variety of disciplines. Hobday (2007) has provided a critical review from five generations of innovation model. The first generation model is defined as technology push developed in the 1950s, followed by demand pull models (1960s 1970s), coupling interactive model (1970s), integrated models (1980s), and the fifth generation systems integration and networking model (post 1990s). The strength of each generation of models served as a foundation for more sophisticated models allowing the integration of additional factors that is necessary to the innovation process.

Ernst \& Young (2011) emphasize on the collaboration with various stakeholders, explore new distribution channels, and focus on the efficiency of the production process. Therefore, firms are able to innovate even though they lack of resources to implement research and development activities. The authors developed four perspectives to be met in innovation which includes customer insight, research and development activities, 
people and culture in that firms should value employees' talent and expertise, and finally the operations and business model that enable efficiency in the production operation.

After the above presentation on innovation we now turn to the conceptualization of innovation capability. Although innovation and innovation capability have been used interchangeably in the innovation literature, scholars have attempted to distinguish the term based on various constructs. Innovation capability, as Romijn and Albaladejo (2002, p. 1054) argue is the "skills and knowledge needed to effectively absorb, master, and improve existing technologies, and to create new ones"; while Chen (2009, p. 48) defined innovation capability as " a firm's capabilities, grounded in the processes, systems, and organizational structure, which can be applicable to the product or process innovation activities. Along the same lines, Lawson and Lawson \&Samson (2001) state that innovation capability is the ability to continuously transform knowledge and ideas into new products, processes, and systems for business performance. These definitions stress on capabilities in developing new technology, product, and process. For Hii and Neely (2000), innovation capability focuses on generation of new ideas, identification of new market opportunities and implementation of marketable innovations. It is important to note that, however, scholars presented innovation capability as a synthesis of capabilities (cited in Breznik\&Hisrich, 2014).

Besides variations in definitions of innovation capability, scholars have attempted to develop typology of capabilities. For example, Collis (1994, quoted in Breznik\&Hisrich, 2014) proposed four phases of capabilities. He emphasized the importance of the last phases of capability - the secondorder capability, which is related to the learning-to-learn capability that enables firms to innovate faster and efficiently. Having explained the key theoretical concepts in this study, the barriers to innovation is presented next.It should be noted that the majority of innovation capability studies are grounded in a functionalist perspective and concentrated in large firms. Specifically, the mainstream literature on women entrepreneurs and innovation do not adequately explored deeper into women perspective on innovation capability and factors limiting their innovativeness. Women entrepreneurs are important as they play the roles of reducing poverty and unemployment by participating in small businesses. In addition, a conducive environment that creates innovation awareness is needed to allow entry for women entrepreneurs to improve their products.

Fogelberg (2014), highlighted the importance of understanding the gendered dimensions of innovation. Hence, considering the fact that innovative capabilitycan strongly influence the sustainability of women-owned businesses in this highly competitive global marketplace, it is necessary to develop a deeper understanding of ways in which women articulate their innovativeness. It is imperative that a better insight of women entrepreneurs' capacity to innovate and their constraints they face is made, so as to develop appropriate assistance programs and policies.
Furthermore, previous studies show that the predominant work on women entrepreneurs and innovation was descriptive, lack of theoretical foundation and grounded in objectivist paradigm (see for example Tepic et al., 2014; Guijarro et al., 2009; Zhou \& Wu, 2010) which lack of depth in terms of understanding the phenomena. Moreover, the lack of scholarly writing by local researchers exploring the field of gender and innovation in a nonnormative field of research using an interpretivistparadigm, is especially apparent. Given the fact that entrepreneurs is seen agendered, little attempt has been taken to explore innovation capabilities among women entrepreneurs. Much less attention has, however, been paid to the innovation attempt by women entrepreneurs who dominated the smaller firms. Women are faced with specific obstacles (such as family responsibilities) that have to be overcome in order to give them access to the same opportunities as men. The contribution of women entrepreneurs is not only for economic development and wealth creation, but also on the diversity of entrepreneurial activity which include their ability to innovate and improve product performance. For that reason, this study aims to explore how women entrepreneurs construct the innovation concept and process, along with the factors that influence the development of the innovative capability. Therefore based on the above discussion the following theoretical model is developed.

The literature review above informs the proposed theoretical framework (Figure 1.0) for this study. This study also develop and extend Inan's and Bititci's (2016) model on their analysis of innovation capability in microenterprises to frame the analysis of how women entrepreneurs make sense and construct innovation capability in multiple ways. The framework consists of internal factors (micro) such as leadership skills, owner's knowledge and expertise, and family members of the firm. The external (macro) factors comprises of customer engagement (response), networking and coalition (collaboration). 


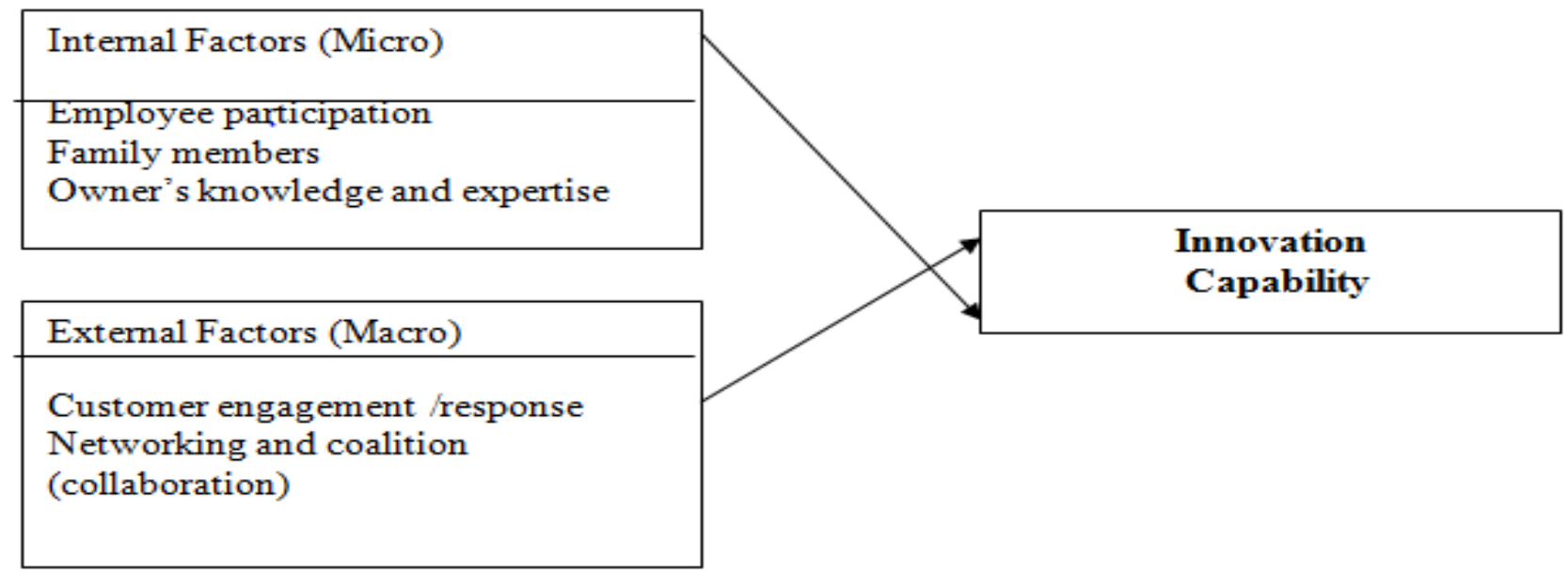

Fig 1.Theoretical Framework

\section{METHODOLOGY}

In the broadest sense, methodology refers to "a way of thinking about and studying social phenomena" (Corbin \& Strauss, 2008, p. 1). It concerns how research is conducted and the strategies or action plans used in that research (Creswell, 2003). It focuses on the best way of acquiring knowledge about the world we live in (Denzin\& Lincoln, 2003). Research in gender in management studies has been traditionally dominated by a functionalist paradigm that embraces quantitative methodologies (Bygrave, 2007; Wigren, 2007). The decision regarding which methodology to use in any research investigation is influenced by the researcher's assumptions, interests, and aims in seeking answers to the research question(s) (Boeije, 2010).

A qualitative approach is relevant to this study as it enables researchers to generate thick description of the social actors in their natural setting (Denzin\& Lincoln, 2003). This approach is chosen for a number of reasons; the aim of qualitative research is one of understanding, therefore the goal of the researcher is to expand and generalise theorises. It is not to establish the frequency with which a phenomenon occurs (Braun and Clarke, 2009; Hyde, 2000). Also, as the topic itself is still at the very early stages of research, an exploratory perspective is appropriate. Merriam (2002) asserts that qualitative research focuses on "how meaning is constructed, how people make sense of their lives and their worlds" (p.39).

Women entrepreneurs were identified through various websites that listed women entrepreneurs businesses. Cold calls were made explaining the purpose of this research and the interview appointments was made. The majority of the women participants resides in the Northern state. The Northern state was chosen in that the country has experienced steady growth and has the advantage of enabling Malay women entrepreneurs to participate and innovate their business activities. All interviews were conducted at locations that were convenient to participants, for example, at their work locations, or their homes. All the interviews were conducted in the Malay language and then the transcripts were translated into English language.

A semi-structured interview was used to collect the data in this study. A semi-structured interview was chosen in preference to an unstructured interview because of the need to focus on specific topics and issues. As Rubin and Rubin (1995) note, the interviewer starts the conversation by introducing the topic and asking particular questions as guidance for a further discussion. The researcher is then free to follow new leads as they occur (Fontana \& Frey, 2003). May (2001) describes the strength of semi-structured interviews where the interviewer can seek clarification and elaboration of the interviewees' responses and thus encourage further discussion on a particular topic. A total of 10 women entrepreneurs were interviewed in order to understand the innovation that was done and how do they develop their innovation capability. Interviews lasted approximately 50 to 90 minutes, and were fully transcribed. Next, the data analysis method is outlined.

As suggested by Braun and Clarke (2006), thematic analysis is a flexible method of analysis which can yield a rich and detailed account of data. They add that, because of its flexibility, this approach is not limited according to particular epistemological approaches and is compatible with both a realist and a constructivist paradigm.

\section{FINDINGS AND DISCUSSION}

\section{Demographic Profile of the Women Participants}

It is useful to begin with some demographics about the sample in order to provide a context for the result that follow. 
Table 1.Demographics for Interview Participants

\begin{tabular}{llccc}
\hline Types of Business & Pseudonym & Age & Marital Status & $\begin{array}{c}\text { Length of Business } \\
\text { Experience }\end{array}$ \\
& & & & \\
\hline Traditional cookies & Mastura & $40 \mathrm{~s}$ & Married & 5 years_ \\
Bakery & Suzana & $40 \mathrm{~s}$ & Married & 10 years \\
Paste (Chilli) & Anita & $40 \mathrm{~s}$ & Married & 7 years \\
Paste & Khalijah & $40 \mathrm{~s}$ & Married & 10 years \\
Bakery & Karimah & $40 \mathrm{~s}$ & Married & 6 years \\
Pizza & Shahida & $40 \mathrm{~s}$ & Married & 5 years \\
Traditional cookies & Yana & $50 \mathrm{~s}$ & Married & 15 years \\
Herbal drink & Siti & $50 \mathrm{~s}$ & Married & 5 years \\
Spices & Laila & $40 \mathrm{~s}$ & Married & 5 years \\
Traditional cookies & Rahimah & $30 \mathrm{~s}$ & Married & 5 years \\
& & & & \\
\hline
\end{tabular}

As illustrated in table 1, the sample comprises 10 married women entrepreneurs. They engage in various types of food businesses. The majority of the sample are in their 40s. All of the women entrepreneurs have more than five years experience in their own businesses. Pseudonyms are used for the purpose of confidentiality of their identities. Next, we demonstrate how women entrepreneurs articulate the term innovation in their own words.

\section{Understanding innovation}

The primary objective of the first part of this chapter is to address research question one, which is aimed toward understanding what innovation means. Thematic analysis was undertaken using the six-step approach (Braun \& Clarke, 2006) described in the previous chapter. In order to understand how women entrepreneurs construct or develop their innovation capability it is primarily important to interrogate their understandings about innovation. We explorehow women participants draw upon their understandings about innovation from their entrepreneurial contexts. They describe innovation in various terms.

\section{Ability or capacity to use machine - changes in the} production process

The most common theme that emerges from the women participants here is that they describe innovation as being able to use machine in order to improve the capacity or quantity of the production. In the mainstream literature, an innovation is generally referred to as a new product or service that has been commercialized (Drucker, 2014). However, some of these women participants refer to a different notion. Women understanding about innovation within the context of their businesses can be grouped into two main themes.

Some of the participants construct innovation in terms of using machine technology rather than manual processing of the products. The following excerpts reflect this theme in the data.

...innovation.. . ermmm ... what actually is nnovation?...ohh...it's about changes... I only bought the mixer machine. Previously I use hands (manual)... now I use machine. I have bought 2 machines. Now I can produce faster.
Mastura traditional cookies

Similarly, Suzana who is also in food industry described about the dough mixer at her bakery.

For me innovation is when I can produce my cookies faster than before. Now I have dough mixer, and new oven. It is much easier and faster when I can use new dough mixer.

The chilli paste producer, Anita added:

... talking about other innovation, I can say that I buy more machines, for example chilli paste dryer. I can perform the work faster from the conventional processes.

In an apparently similar fashion, Khalijah also refers to innovation as having a modern technology of the existing machine. In Khalijah's words:

Nowadays everything use technology ... I have added chilli paste processor. I need to separate the chilli and the tomato processor ... I also use packaging and labeling machines now. That's what I can think of innovation in my business. In fact there's no need to employ many workers. And I find it clean too when using machines

Khalijah speaks of innovation in relation to her packaging and labeling machines. She seems to favor using machines in that she finds the handling processes is cleaner when compared with using workers. The ability to use machine appears relevant to three women entrepreneurs. The above quotes reflect the view that being able to have machineries resources would increase the innovation process speed and cleanliness as well. Thus, women entrepreneurs who are equipped with modern technology can capitalize on this strength to be innovative. This part of the finding concurs with Kamariah et al. (2012) view on the relevant of technology in techno-based enterprises.

Invention of new ideas - developing new products

In contrast, some of the women participants speak about innovation in a common term found in the literature such as invention of new ideas or the development of new products. Their construction of the innovation theme appears to be also concerned with something that is new or different, such

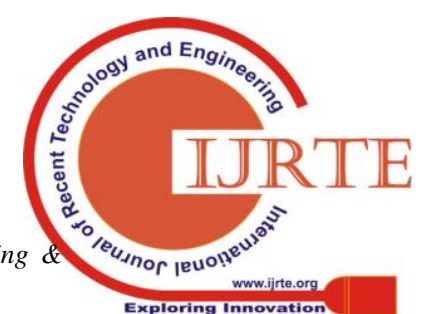


as an invention, rather than just a commercialized product or service.

Here, women entrepreneurs understand innovation as diversifying old product (food item) into something new that can attract customers. This theme is illustrated in the following responses:

we change the appearance of the cake from plain look into colorful, and put makeroon, and also we add in blueberry a little bit to make it taste sour, and we also produce new biscuits

Qistina demonstrated the act of introducing new ideas and innovation in her range of cakes and pastries at her bakery.

Anita added:

Innovation that I've done was in terms of product. Within 6 years I've expanded the spices to sambaltomis paste, kurma, and rendang. ...

Both of these women entrepreneurs focus on the newness or difference of something. This view tends to support Ishak's and Che Omar's (2013) findings that most firms implement product innovation. In addition to these views, Yana and Shahida speak of innovation in terms of making the product taste better as well as extending the product line into several categories. For instance, Yana explains:

I think about innovation as creating something different from the usual, for example I added a few flavors like pandan, orange, cheese, and blueberry. I also create new products such as snacks, and a variety of biscuits.

Shahida also remarks:

It's a matter of be able to create something where it wasn't before ... Also go out and grabs something and creates something out of nothing. That's what I do with the pizza. Pizza is Western food. I tried to embed local flavours which is more spicy than the usual pizza.

The idea presented by these women participants suggests that innovation is recognized as an important factor in order to be competitive (Abdul Rahman et al. 2015; Busaibe et al., 2017). In addition, the women participants in this study view innovation as important for new product development. This theme is in line with the scholarly literature that proposed innovation is concern with generation of new ideas and product (Ishak\&Che Omar, 2013; Lawson \& Samson, 2001; Trott, 2005). The above excerpts highlight the idea that innovation can be seen from multiple perspectives. Next, we present the findings related to the second research question. The next section focuses on the sources of innovation capability towards understanding ways in which women develop their innovation capability.

In the next part of the findings, we aim to understand how do womenentrepreneurs develop their innovation capability in order to answer research question two. In other words we explore the sources of innovation capability of women entrepreneurs. The interview transcripts seem to suggest that customer play an important role in women entrepreneurs' innovation capability.

\section{Customer engagement}

It is widely established that communication and interaction with stakeholders such as customers can increase innovation capability (Inan\&Bititci, 2016). Several women entrepreneurs illustrate how they develop their innovation capability from the suggestion requested by the customers. As mentioned by Karimah:
We follow customers' requirement. We don't have many choices at this bakery. Just plain cakes. Take for an example vanilla chocolate cake. There's one customer who suggested like this "can you change the design of the cake, or diversify the taste?".Then we change the design of the cake from plain look into colorful, and put makeroon, and also we add in blueberry...

\section{Karimah bakery}

In a similar vein, a pizza outlet owner, Sarah, described how she managed to innovate by trying to follow the request by some of her customers:

Nowadays, the customer especially the new generation wants something different. They saw the pizza advertisement in the internet and from other social media. Some of them will say "why don't you do like this... maybe you can change the packaging ... and garnish the pizza with something unique.... So we try to fulfill their requests.

Yana, the cookie producer also elaborated in the following statements:

The customers want something different nowadays. They will compare the products from other shops. We need to listen to their views... Some of them comment about the quality, and say that the cookies are not so tasty. So we will try to improve our cookies.

The above excepts indicate that opportunities of innovation based on the needs of customers can achieve better profitability or generate more values for women entrepreneurs. By focusing on customers' needs and preferences, women entrepreneurs are likely to improve their competitiveness and productivity, and sustaining the growth of the firms as well. Customers are seen as an important source of new ideas. In addition, there is an increasing attention to the rising demand for individualized products according to customer wants and need (Inan\&Bititci, 2016). Therefore, women entrepreneurs can benefit on the suggestions from their customers. Next, we illustrate another sources of innovation capability that is from the participation of the employees.

\section{Employee participation}

While some women participants develop their innovation capability from customer engagement, a few women participants considered their employees play an important role in generating ideas for innovation. The pizza owner remarks:

My employees have been very observant on the trending of the present fast food industry. Usually they've got the idea to innovate the product from the social media, other establish pizza industry and the internet. They will say like "this is what's trending nowadays ... you can do like this....and why don't you put this (like garnish) on the pizza ... and we can change the packaging like this ....and so on ...

Reference to employee participation also was highlighted by Liza who owned a traditional cookies and snacks firm. She explains:

My workers are good in their work. They also contributed in giving creative ideas to sell the products. For example, they tried to create other types of product and showed it to me. Sometimes they will offer to change the recipes and 
make the cookies taste better and different from other products

The above examples show how employee participates in improving the firm's product. Employees generate new ideas from their knowledge on the present trending of the food products. This part of the finding is in line with Inan et al. (2016) that reflect the participation of employees in generating ideas to improve the company's performance. In a competitive, globalized marketplace, firms need to employ innovative employees that can help bring new ideas forward, and reward the employees for their initiatives.

\section{Networking}

Besides customer engagement and employee participation, several women participants construct their sources of innovation form networking and collaboration. Most of the literature on networking behaviors indicate that networking activities have positive impact on innovation activities of the firm (Bogren et al., 2013; Li et al., 2016). Liza, the cookie producer has increased her product range and still continue to invest for new products. Also, Liza has received government funds to improve her machinery capabilities within the last five years. She explains:

I've got machinery grant from the Agriculture Department. I also received other fund from other government sources. In this way I can improve the capacity of my products and be able to innovate and offer new products. Also, the production process is faster when compared with using the old machine. When we are in business it's very important to build network with other supporting agencies such as MARA, bank and others. There are many grants to be grabbed provided that we fulfill the agency's requirement. For example, we need to provide a business plan.

Herbal drink producer, Siti added:

One thing with the government grant is that we must show to the official that we already have a business that is doing well. By this way it will be easier to secure the grant. And of course we must be able to build the network. We've received government grant for a new machine. Alhamdulillah, we can improve the performance of our product ... and with new packaging, new label, the product looks good and competitive as well.

Liza's and Siti's statement shows that without networking activities, it is hard to improve and engage in innovation activities. As a result, the networking activities have positive impact on the development of innovation capability. This part of finding is similar to those of Inan et al (2016) who found that innovation capability is strengthen by networking activities among their interviewees. However, Ultan and Stephens (2016) discovered that the participants in their study of microenterprises in Ireland do not engage in networks because the networks are not appropriate for their needs.

In addition, Teoh and Chong (2014) provide a Malaysian scenario where women entrepreneurs do not utilize the opportunity that women's business networks can offer, due to the family responsibility and the burden of their businesses. This in turn raises the issue of social skills which might prevent her from benefiting from potential networking opportunities. It is worth noting that women entrepreneurs also are able to access new information via their network that can assist them to improve and innovate their products. Thus, networking activities has substantial role in microenterprises for innovation capability development.

\section{Family members and owner's own experience.}

It is interesting to note that one of our women participants considered the family member as an important sources of innovation capability. Siti highlights with proud:

My son is trained in marketing. I noticed that he's interested in this area, and Alhamdulillah he's good in designing and marketing. The product has gone through a few stages of packaging, from the plain design to a new concept and attractive to the customers. My son has initiated in the innovation of the product's packaging.

The above excerpt appears distinctive from the mainstream literature on innovation capability. Family context may primarily influence business innovation in women entrepreneurs as indicated in Siti's case. Being involved many years in the food industry also has enabled the majority of women participants in this study to recognizes new opportunities for innovation. As a result, women attribute their innovation capability from their knowledge, skills, and experiences and expertise. They are able to explore, scan, learn and searches new opportunities in innovating their products. Here, family members and owners own strength play important role in innovation capability. This part of finding on family members supportive behavior contradicts with the study done by Nieto et al. (2013) who found that family firms perform fewer innovation activities which reflect the view that family members spend less effort in innovation. Next we present the findings related to barriers to innovation.

\section{CONCLUSION}

Using an interpretive approach, this study helps to deepen our understanding of the innovation capability and barriers specifically among women entrepreneurs in food-based industry.Based on ten women-owned businesses, the findings indicate innovation was constructed in terms of the ability to capitalize on sophisticated machineries for innovation purposes. In addition, innovation was articulated in the form of new or improved products. Most women entrepreneurs develop their innovation capability from customer engagement, employee participation, networking, and family members as well as from their owned experiences and expertise. Because networking enables businesses to access various resources and opportunities for innovation purposes, women entrepreneurs should capitalized more on the heterogeneity of their network. Being able to collaborate with different organizations can contribute to their innovation capability positively. As women entrepreneurs view their capability favorably, they cannot remain complacent but need to strategically develop their strength effectively in the long run. Innovation capabilities underpin women entrepreneurs' competitive advantages as well as their ability to respond to external and internal changes. Women entrepreneurs are able to cope with rapidly changing environment by utilizing and capitalizing their innovation capabilities.

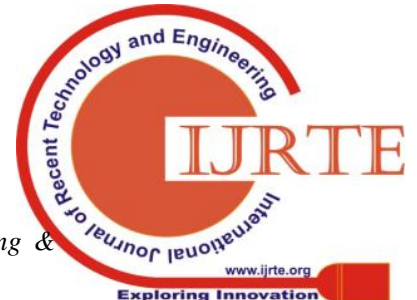


Women entrepreneurs represent an important source of growth and development in almost all economies in the world. They are becoming more prominent and continued to make tangible contributions towards social and economic development as well. From a policy perspective, the findings of this is hoped to benefit the government and relevant parties in understanding and implementing suitable strategies that can help to increase the innovation capability among women entrepreneurs in Malaysia. Initiativeto overcome constraints to innovation in women's businesses should be given a priority. In order to improve their products, women entrepreneurs need more support in terms of resource funding, and training to better equip them with current innovation practices. Innovation programs specifically aimed at women entrepreneurs should be delivered effectively by the relevant agencies. Women entrepreneurs need to exploit knowledge to create new opportunities in which innovation might be developed and enhanced.

\section{ACKNOWLEDGMENT}

This research has been funded by Universiti Pendidikan Sultan Idris, Malaysia through the University Research Grant (Research Code: 2016-0039-106-01).

\section{REFERENCES}

1. AbRahman, M. N., Doroodian, M., Kamarulzaman, Y., \& and Muhamad, N. (2015). Designing and validating a model for measuring sustainability of overall innovation capability of small and mediumsized enterprises. Sustainability, 7, 537-562.

2. Agarwal, S., \&Lenka, U. (2015). Study on work-life balance of women entrepreneurs - review and research agenda. Industrial and Commercial Training, 47(7).

3. Al Mamun, A., Rajennd, A., Muniady, L., Permarupa, P. Y., Zainol, N. R. B., Nawi, N. B. C., \&Malarvizhi, C. A. (2016). Social capital and entrepreneurial competencies: A study among women microentrepreneurs in Malaysia. The journal of developing areas, 50(5), 363370.

4. Ambepitiya, K. R. (2016). The Role of Women Entrepreneurs in Establishing Sustainable Development in Developing Nations. World Review of Business Research, 6(1), 161-178.

5. Aziz, Y. A., Khairil, W. A \&Zalton, S. (2012). Challenges faced by micro, small, and medium lodgings in Malaysia. Int. Journal of Economics and Management ,6(1), 167-190.

6. Babalola, S. S. (2006). Managing innovation, product development and entrepreneurship. In S. Balogun, B. Ehigie, \& A. Sunmola (Eds.), Managerial psychology: An overview. Nigeria: University of Ibadan, Department of Psychology Publication. pp. 352-387.

7. Baregheh, Anahita , Rowley, J., \&Sambrook, S. (2009). Towards a multidisciplinary definition of Innovation. Management Decision, 47(8), 1323-1339.

8. Barczak, G., Griffin, A. \& Kahn, K.B. (2009). "PERSPECTIVE: Trends and drivers of success in NPD Practices: Results of the 2003 PDMA Best Practices Study. Journal of Product Innovation Management, 26(1), 3-23.

9. Boeije, H. (2010). Analysis in qualitative research. London: Sage.

10. Bogren, M., von Friedrichs, Y., Rennemo, Ø.,\&Widding, Ø. (2013). Networking women entrepreneurs: fruitful for business growth?. International Journal of Gender and Entrepreneurship, 5(1), 60-77.

11. Braun,V., \& Clarke, V. (2006). Using thematic analysis in psychology. Qualitative research in psychology, 3(2), 77-101.

12. Breznik , L. D., \&Hisrich, R. (2014). Dynamic capabilities vs. innovation capability: are they related? Journal of Small Business and Enterprise Development, 21(3), 368 - 384.

13. Brush, C.G. and Cooper, S. (2012). Female entrepreneurship and economic development: An international perspective. Entrepreneurship and Regional Development: An International Journal, 24(1-2), 1-6.
14. Busaibe, L., Singh, S. K., Ahmad, S. Z., \& Gaur, S. S. (2017). Determinants of organizational innovation: a framework. Gender in Management: An International Journal, 32(8), 578-589.

15. Bygrave, W. D. (2007). The entrepreneurship paradigm (I) revisited. In H. Neergaard\& J. P. Ulhoi (Eds.), Handbook of qualitative research methods in entrepreneurship (pp. 17-48). Cheltenham, UK: Edward Elgar.

16. Cáceres, R., Guzmán, J., \&Rekowski, M. (2011). Firms as source of variety in innovation: Influence of size and sector. International Entrepreneurship Management Journal, 357-372.

17. Chell, E. (2001). Entrepreneurship: Globalisation, Innovation and Development. London: Thomson.

18. Corbin, J. A., \& Strauss, A. (2008). Basics of qualitative research, 3rd ed. Thousand Oaks, CA: Sage.

19. Creswell, J. W. (2003). Research design: Quantitative, qualitative, and mixed methods approaches. Thousand Oaks: Sage.

20. Crossan, M. M., and Apaydin, M. (2010). A multi-dimensional framework of organizational innovation: A systematic review of the Literature. Journal of Management Studies 47(6), 1154-1191

21. Dakhli, M., \& D.D. Clercq, D. D. (2004). Human capital, social capital and innovation: A multi-country study. Entrepreneurship and Regional Development, 16(2),107-128.

22. Department of Statistics, Malaysia. (2016). Key Facts. Retrieved March 20, 2018 from http://www.statistics.gov.my

23. Denzin, N. K., \& Lincoln Y. S. (Eds.). (2003). Collecting and interpreting qualitative materials (2nd.ed.). Thousand Oaks, CA: Sage.

24. Drucker, P. (2014). Innovation and entrepreneurship. Routledge: NY.

25. Ernst \& Young. (2011). Growing beyond: Innovating for the next three billion. EYGM Limited.

26. Fernandez, S., \& Wise, L. R. (2010). An exploration of why public organizations ingest innovations. Public Administration, 88(4), 979998 .

27. Fogelberg Eriksson, A. (2014). A gender perspective as trigger and facilitator of innovation. International Journal of Gender and Entrepreneurship, 6(2), 163-180.

28. Fontana, A., \& Frey, J. (2003). The interview: From structured questions to negotiated text. In N. K. Denzin\& Y. S. Lincoln (Eds.), Collecting and interpreting qualitative materials (2nd. Ed)( pp. 61 106). Thousand Oaks, London: Sage Publications.

29. Goswami, A., \&Dutta, S. (2018). Empowering Women Entrepreneurs in India With ICT Applications. In Handbook of Research on Women's Issues and Rights in the Developing World (pp. 269-280). IGI Global.

30. Guijarro, A. M., Garcia, D., \& Van Auken, H. (2009). Barriers to innovation among Spanish manufacturing SMEs. Journal of Small Business Management, 47(4), 465-488.

31. Gundry, L. K., Kickul, J. L., Lakovleva, T., \&Carsrud, A. L. (2014) Women-owned family businesses in transitional economies: Key influences on firm innovativeness and sustainability. Journal of Innovation and Entrepreneurship, 3(8), 2-17.

32. Hansen, A., Jungbluth, C., Hees, F., \&Jeschke, S. (2011). Strategies and characteristic of the innovative capability of small and medium sized enterprises: Research results from Germany. Paper presented at 5thInternational Technology, Education and Development Conference, 7-9 March in Valencia, Spain.

33. Heimonen, T. (2012). What are the factors that affect innovation in growing SMEs? Europeran Journal of Innovation Management, 15(1), 122-144.

34. Hewitt-Dundas. (2006). Resource and capability constraints to innovation in small and large plants. Small Business Economics, 26, 257-277.

35. Hirsch-Kreinsen. (2015). Patterns of knowledge use in low tech industries. Critical studies in innovation, 33(1), 67-82

36. Hogan, S. J., Soutar, G. N., McColl-Kennedy, J. R., \& Sweeney, J. C. (2011). Reconceptualising professional service firm innovation capability: Scale development. Industrial Marketing Management, 40, 1264-1273.

37. Hobday, M (2005). Firm-level Innovation Models: Perspectives on Research in Developed and Developing Countries. Technology analysis and strategic management, 17(2), 121-146.

38. Hii, J., \& Neely, A. (2000). Innovative capacity of firms: On why some firms are more innovative than others. Paper presented at $7^{\text {th }}$ International Annual EurOMA Conference, June, Ghent. 
39. Hill, C.W.L., \&Rothaermel, F. T. (2003). The performance of incumbent firms in the face of radical technology innovation. Academy of Management Review, 28(2), 257-274.

40. Hyde, K. F. (2000). Recognising deductive processes in qualitative research. Qualitative market research: An international journal, 3(2), 82-90.

41. Ilhaamie, G. A. (2014) Challenges of Muslim Women Entrepreneurs in Malaysian SMEs. International Journal of Innovation, Management and Technology, vol. 5.

42. Inan, G.G., \&Bititci, U. S. (2016). Understanding innovation capability in micro enterprises. Conference Paper, ResearchGate publication.

43. Ishak, S., \&Che Omar, A. R. (2013). Do small firms possess innovative behavior? Evidence from Malaysia. Journal of Innovation Management in Small and Medium Enterprises. Vol. 2013 (2013), Article ID 815384, DOI: 10.5171/2013. 815384.

44. Kamariah, I., Khurram, A. J., Wafa, K., \&Khairiah, S. (2012). Linking the dots: Innovative capability and sustainable growth of women owned technoprises in Asian developing countries. International Journal of Academic Research in Business and Social Science, vol. 2.

45. Kodama, M. (2017). Developing strategic innovation in large corporations - The dynamic capability view of the firm. Knowledge and Process Management, 24(4), 221-246.

46. Lai, Nathan, Tan, \& Chan (2010). Effect of innovation to the success of female entrepreneurs: Journal of innovation management in small and medium enterprises.

47. Lawson, B., \& Samson, D. (2001). Developing innovation capability in organizations: A dynamic capabilities approach. International Journal of Innovation Management, 5(3), 377-400.

48. Li, J., Chen, Z., \&Schøtt, T. (2016). Innovation benefitting exporting: benefit enhanced by transnational networking. International Journal of Business and Globalisation, 16(3), 245-263.

49. Löfsten . Hans (2014). Product innovation processes and the trade-off between product innovation performance and business performance. European Journal of Innovation Management, 17(1), 61-84.

50. Marlow, S., Henry, C. and Carter, S. (2009). Exploring the impact of gender upon women's business ownership: Introduction. International Small Business Journal, 27(2): 139-148.

51. May, T. (2001). Social research. Issues, methods and process. ( $\left.3^{\text {rd }} e d\right)$. Buckingham: Open University Press.

52. Merriam, S. B. (2002). Qualitative research in practice. San Francisco: Josey-Bass.

53. MohdRosli, M., \&Sidek, S. (2013). The Impact of Innovation on the Performance of Small and Medium Manufacturing Enterprises: Evidence from Malaysia. Journal of Innovation Management in Small \& Medium Enterprise. http://www.ibimapublishing.com/journals/JIMSME/jim

54. National Association of Women Entrepreneurs of Malaysia (NAWEM). (2016). PenerbitanStatistikMilikan Wanita,https://www.nawem.org.my/images/04_Newsroom/01_2018_Ja nuary/PENERBITAN_STATISTIK_MILIKAN_WANITA\%20_2016. pdf

55. Nieto, M.J, Santamaria, L, and Fernandez, Z (2013). Understanding the Innovation Behavior of Family Firms. Journal of Small Business Management, 1-18.

56. Nählinder, J., Tillmar, M., \&Wigren, C. (2015). Towards a genderaware understanding of innovation: a three-dimensional route. International Journal of Gender and Entrepreneurship, 7(1), 6686.

57. Obeidat, B. Y., Al-Suradi, M. M., Masa'deh, R. E., \&Tarhini, A. (2016). The impact of knowledge management on innovation: An empirical study on Jordanian consultancy firms. Management Research Review, 39(10), 1214-1238.

58. Peeters, L. W., \&Ateljevic, I. (2017). Women empowerment entrepreneurship nexus in tourism: Processes of social innovation. In Tourism and Entrepreneurship (pp. 94-109). Routledge.

59. Prajogo, D. I., C. M. McDermott, M. A. McDermott. (2013). Innovation orientations and their effects on business performance: Contrasting small and medium sized service firms. R\&D Management, 43(5): 486-500.

60. Prelazzi, D. (2009). Innovation \& Commercialization: Rising to the challenge through business acceleration ecosystem. Working Paper, British Columbia Innovation Council.
61. Ramadani, V., Hisrich, R. D., \&Gërguri-Rashiti, S. (2015). Female entrepreneurs in transition economies: insights from Albania, Macedonia and Kosovo. World Review of Entrepreneurship, Management and Sustainable Development, 11(4), 391-413.

62. Rehman, R., \&Roomi, M. A. (2012). Gender and work-life balance: a phenomenological study of women entrepreneurs in Pakistan. Journal of Small Business and Enterprise Development, 19(2), 209-228.

63. Roig-Tierno, N., Kraus, S., \& Cruz, S. (2018). The relation between coopetition and innovation/entrepreneurship. Review of Managerial Science, 12(2), $379-383$.

64. Romijn, H., \&Albaladejo, M. (2002). Determinants of innovation capability in small electronic and software firms in southeast England. Research policy, 31, 1053-1067.

65. Rubin, H. J., \& Rubin, I. S. (1995). Qualitative interviewing: The art of hearing data. Thousand Oaks, CA: Sage Publications.

66. Schumpeter, J. A. (1934). The theory of economic development. Cambridge, MA: Harvard University Press.

67. Shoham, A., \&Fiegenbaum, A. (2002), Competitive determinants of organisational risk-taking attitude: the role of strategic reference points. Management Decision, 40(2), 127-141.

68. Subrahmanya, M. H. B., Mathirajan, M., \&Krishnaswamy, K. N. (2010). Importance of technological innovation for SME growth: Evidence from India. Working paper, UNU-WIDER.

69. Syed, J. (2010). An historical perspective on Islamic modesty and its implications for female employment: Equality, diversity and inclusion: An International Journal, 29(2),150-166.

70. Tambunan, T. T. H. (2011). Development of small and medium enterprises in a developing country: The Indonesian case. Journal of Enterprising Communities: People and Places in the Global Economy, 5 (1), pp.68-82.

71. Tepic, M., Kemp, R., Omta, O., \&Fortuin, F. (2013). Complexities in innovation management in companies from the European industry: A path model of innovation project performance determinants. European Journal of Innovation Management, 16, 517-550.

72. Teoh, W. M. Y., \& Chong, S. C. (2007). Theorizing a framework of factors influencing performance of women entrepreneurs in Malaysia. Journal of Asia Entrepreneurship and Sustainability, 3(2), 42-59.

73. Teoh, W. M. Y., \& Chong, S. C. (2014). Towards strengthening the development of women entrepreneurs in Malaysia. Gender in Management: An International Jjournal, 29(7), 432-453.

74. Terjesen, S., Hessels, J., \& Li, D. (2016). Comparative international entrepreneurship: A review and research agenda. Journal of Management, 42(1), 299-344.

75. Thornhill, S. (2006). Knowledge, innovation and firm performance in high-and low-technology regimes. Journal of business venturing. 21, 687-703.

76. Trott, P. (2005). Innovation management and new product development. $3^{\text {rd }}$ edition. Financial Times/Prentice Hall: Harlow, England.

77. Wang, X., Manry, D., \&Wandler, S. (2010). The impact of government ownership on dividend policy in China. Working paper, University of New Orleans.

78. Wigren, C. (2007). Assessing the quality of qualitative research in entrepreneurship. In Neergaard, H., \& P. Ulhoi (Eds.), Handbook of qualitative research methods in entrepreneurship (pp. 383-405). Cheltenhamn, UK: Edward Elgar.

79. World Development Report, 2012

80. Wolff, J.A., \&Pett, T.L. (2006). Small-firm performance: modeling the role of product and process improvements. Journal of Small Business Management, 44(2), 268-2.

81. Yu, Z., \&Yanfei, W. (2009). The strategic role of innovative capabilities in the relationship among social capital, knowledge sharing and firm performance. Proceeding of International Conference on Management and Service Science (MASS '09), pp: 1-4.

82. Yuanjian, Q., Feiyue, Z., \&Hongchuang, L. (2011). Research on the Critical Success Factors of Advanced Manufacturing Services in Hubei Province of China. Paper presented at 7th International Conference on Innovation and Management, pp. 438-443.

83. Zhou, K. Z., \& Wu, F. (2010). Technology capability, strategic flexibility, and product innovation. Strategic Management Journal, 31(5), 547-561. 